\title{
The Motivation Level of Male and Female Academicians a Comparative Study (Special Concern to Professional Academicians)
}

\author{
Tulsee Giri Goswami and Dr. Harsh Dwivedi
}

\begin{abstract}
Motivation in simple terms may be understood as the set of forces that cause people to behave in certain ways. A motivated academician generally is more quality oriented. Highly motivated employees are more productive than apathetic employee, one reason why motivation is a difficult task is that the workforce is changing. Employees join institutions with different needs and expectations. Their values, beliefs, background, lifestyles, perceptions and attitudes are different. Not many institutions have understood these and not many HR experts are clear about the ways of motivating such diverse workforce. The present paper is an attempt to identify the factors determining the motivational level of male and female academicians.
\end{abstract}

Index Terms-Motivation, Academician, Psychological Androgyny

\section{INTRODUCTION}

Now a day's employees have been hired, trained and remunerated and also need to be motivated for better performance. Motivation in simple terms may be understood as the set or forces that cause people to behave in certain ways. People are motivated rewards something they can relate to and something they can believe in. Times have changed People wants more. Motivated employees are always looking for better ways to do a job. It is the responsibility of managers to make employees look for better ways of doing their jobs.

Individuals differ not only in their ability to do but also in their determinations to do, or motivation managers who are successful in motivating employees are often providing an environment in which appropriate goals are available for needs satisfaction. Retaining and motivating workers requires special attention and the responsibility falls squarely on the shoulders of HR as well as managers and supervisors at all level. They have to create a work environment where people enjoy what they do, feel like they have a purpose and have pride in the mission of the organization. It requires more time, more skill, and managers who care about people. It takes true leadership.

By giving employees special tasks, you make them feel more important. When your employees feel like they are

Tulsee Giri Goswami is a Research scholar at University of Rajasthan, Jaipur. She is Management Graduate from Maharshi Dayanand University, Ajmer. Since last 7 Yrs she is in teaching profession, her area of research is Behavioral Sciences.

Dr. Harsh Dwivedi is Associate Professor and Director R A Podar Institute of Management, University of Rajasthan, Jaipur. being trusted with added responsibilities, they are motivated to work even harder so they won't let the company down.

Motivation is essential for any institution because employees are the pertinent intellectual Assets of company. Motivation is important for the growth of employees as well as for contributing organizational productivity.

\section{ReSEARCH PROBLEM:}

In present research the problem is "To compare the level of motivation among male and female professional academicians".

\section{ObJectives Of The Study:}

The present study will be carried out by keeping in view the following objectives.

1) To compare the level of motivation among male and female academicians

2) To analyze the implication of Maslow's need hierarchy and Herzberg's two factor theory on professional academicians.

3) To analyze the weight of each factor in order to find out what is the preference of professionals for achieving higher level of motivation

\section{REVIEW OF LITERATURE}

The extensive literature has been surveyed for making the research purposeful. According to Smita Kulkarni as discussed in her article (Employee Motivation, Global CEO, November 2005, Volume VII) balancing the demand of the changing market with work specific facility/need/demand of the academicians for reasonable assistance / treatment and respect is becoming increasingly difficulty. According to Radha Mohan Chebolu (Employee Empowerment - A work place strategy for Motivation, HRM Review, February 2005, volume VI) the concept of "employee empowerment" in the corporate world is about the need for a revolutionary, integrated, employee oriented leadership philosophy, with an emphasis on transformation of an institution by tapping the full potential of every employee.

There is a study by Fiona J. Lacy \& Barry A. Sheehan (University of Melbourne, Parkville, Australia) it examined aspects of academics' satisfaction with their jobs across the eight nations (Australia, Germany, Hong Kong, Israel, Mexico, Sweden, UK, USA). Interesting patterns emerged across countries reflecting differences in the international 
academic climate.

Mark R. reviewed regarding self-related motives (self-enhancement, self-verification, and self-expansion) and self-conscious emotions (guilt, shame, pride, social anxiety, and embarrassment), with an emphasis on how these motivational and emotional aspects of the self might be related. The research work of Kathy J. Young and Theresa J.B. Kline examined the effects of perceived 1) self-efficacy, 2) outcome-efficacy, and 3) feedback on motivation to improve university teaching through teaching development workshops.

As per Middlebrook-Stangl, Ann there is relationship between androgyny and self-esteem. Androgyny research is cited that showed a distinct class of people whose sex-role adaptability allowed them to use male and female behaviors in a way that promoted flexibility and independence. It is noted that increased self-esteem may be hypothesized to accompany such flexibility.

Ellen Piel Cook University of Cincinnati who discussed Androgyny represents a combination of personality characteristics traditionally associated with men (masculine) and those associated with women (feminine). This critical review provides an overview of basic assumptions, measures, research topics, and results of research in the androgyny literature. In particular, research on developmental perspectives emphasizes the importance of focusing upon how individuals systematically maintain and modify their perceptions and experiences as men and women over the life span. The impact of client and practitioner femininity and masculinity upon the counseling process remains poorly understood. Researchers and practitioners alike should recognize the complexity of sex-role-related phenomena, including the importance of situational factors and the role of individual differences in accounting for sex role behavior and adjustment.

Aldora G. Lee and Vernene L. Scheurer said although psychological androgyny has been theoretically related to greater interpersonal and situational adaptability, the relationship between the two has not been articulated.

An interesting exception in Bailey, et al (1997) was that women who described themselves as masculine were more likely to request masculine partners. This may in part be due to the well supported theory that similarity promotes interpersonal attraction (Feingold, 1988; Murstein, 1972).

Research Methodology:

The present study is based on the primary and secondary data. Primary data provide a firsthand account of the situation. Primary data is the only way of finding out opinions, personal qualities, and attitudes. In present research study structured questionnaires was used by researcher for collecting primary data from various institutes of management studies out of four major cities of Rajasthan i.e. Jaipur, Ajmer, Jodhpur, Bikaner. While source for secondary data were collected from published and unpublished literature.

In present research study the samples are non probability sample based on convenience sampling technique element for the sample are selected for the convenience of researcher. The researcher naturally has chosen elements that are readily available, nearby, easy to reach, willing to participate.

\section{HyPOTHESIS ANALYSIS:}

Motivation is a very interesting topic for research, though numerous research studies have been conducted at many times. Inspite of that researcher have chosen the same topic with uniqueness in hypothesis. i.e. Psychological Androgyny. H1. Motivation level (Need satisfaction level as per adapted model of Maslow's Hierarchy of eight levels of need) is much higher amongst those professionals who maintain psychological androgyny personality than only male or female personality characteristics. So researcher analyze this uniqueness by using a standardize BSRI (Bem Sex Role Inventory). For calculating androgyny score a statistical test (t- test) is used i.e. Bem score $=$ Average Feminine traits minus Average Masculine trait and it was found that Bem Score -0.695 shows the sample population is Psychologically Androgyny.

After analyzing the psychological androgyny uniqueness of sample population, researcher found that the level of motivation and need satisfaction is high amongst almost all androgyny people. It was found that only $5 \%$ to $7 \%$ of sample population feels medium or low level of motivation and need satisfaction. While ranking these analyzed data the Biological and Physiological need comes at first rank, as $98.75 \%$ of the sample population is highly satisfied at this level of need according to adapted model of need hierarchy, Cognitive need comes at second rank, as $97.5 \%$ of the sample population is highly satisfied at this level of need, but according to adapted model of need hierarchy safety need comes at second level. Safety need comes at third rank, as $96.25 \%$ of the sample population is highly satisfied at this level of need, and as per adapted model of need hierarchy belongingness and love needs comes at third level. Transcendence need comes at forth rank, as $96 \%$ of the sample population is highly satisfied at this level of need, and adapted model of need hierarchy says Esteem need comes at forth level. Belongingness and Love need comes at fifth rank, as $95.5 \%$ of the sample population is highly satisfied at this level of need, whereas in adapted model of need hierarchy it comes at third level. Aesthetic need comes at Sixth rank, as $95 \%$ of the sample population is highly satisfied at this level of need, and according to adapted model of need hierarchy this comes at same level. Esteem need comes at Seventh rank, as $94.5 \%$ of the sample population is highly satisfied at this level of need, but according to adapted model of need hierarchy esteem need comes at forth level. Self Actualization need comes at Eighth rank, as $93 \%$ of the sample population highly satisfied at this level of need, and according to adapted model of need hierarchy this need comes at seventh level. Researcher come with the conclusion that the level of satisfaction and motivation is high among professional academicians but the level of hierarchy are not rigid.

And according to $\mathrm{H} 2$ Motivational factors lead to higher motivation and job satisfaction, but the absence of these factors will not lead to lower motivation and dissatisfaction. And H3 Lack of hygienic factors lead to lower motivation and dissatisfaction but presence of these will not lead to higher motivation or job satisfaction. Researcher found that there is some controversy in relationship of factors at work place with the level of motivation/ satisfaction and 
demotivation/ dissatisfaction. Due to exceptional cases some of the hygienic factors are also associated to motivation and satisfaction along with the level of demotivation and dissatisfaction i.e. if we see working condition exceptional responded association with motivation and satisfaction but as per Herzberg's two factor theory working conditions are associated with only demotivation and dissatisfaction, but in exceptional cases by providing healthy working conditions as per the expectations of employees their level of motivation and satisfaction can be increased to some extent. A handsome and attractive Salary package is also helpful to increase the level of motivation and satisfaction among employees in some cases. Some time Status is also preferred by employees to increase their level of motivation and satisfaction at work place. Though from majority point of view Job Security is associated with demotivation and dissatisfaction only but in exceptional cases it increases the level of motivation and satisfaction among employees. For reducing the level of dissatisfaction and demotivation among employees, institutions should provide job security to employees.

There are some controversies in association of motivator factors also because of exceptional cases some of the motivator factors are also associated to demotivation and dissatisfaction along with the level of motivation and satisfaction e.g. Recognition though majority respond that it is associated with motivation and satisfaction only but exceptional cases say if employees do not receive proper recognition for efforts they may feel demotivated and dissatisfied at work, institution must have to organize recognition programs for increasing the level of motivation/ satisfaction and also for reducing the level of demotivation and dissatisfaction among employees at work place. Sometimes when employees do not get work as per their caliber and choice, in such cases work itself lead for demotivation and dissatisfaction. While giving any assignment to employees, management must consider their expectation, interest and caliber to keep them motivated/satisfied and to also reducing the level of demotivation and dissatisfaction. Some respondent observed that Responsibility also is associated with demotivation and dissatisfaction at work place. While giving any work responsibility to employees management must consider their expectation, interest and caliber to keep them motivated/satisfied and to also reducing the level of demotivation and dissatisfaction.

\section{RECOMMENDATION:}

Following are some recommendations on the basis of researcher's analysis and findings

\section{A. Recommendations for Management Institutes}

4) The Management of professional institutions should listen to the view point of academicians in decision making and should also invite their participation for the same

1) The Management of professional institutions should punish slackers, so that equality can be maintained without any biasness

2) The Management of professional institutions should also provide sufficient challenge to academicians for improving competency and team spirit

3) The Management of professional institutions should also provide coaching, counseling and mentoring as required by academicians

4) The Management of professional institutions should always reward and recognize and star performers

5) The Management of professional institutions should remember to Say 'Thank You' for any assistance other than routine job at work place

6) The Management of professional institutions should always show keen interest in solving any dysfunctional work group conflicts and also insist functional conflict amongst academicians so that the overall performance can be improved with team spirit

7) The Management should always appreciate employees for their individual strengths and support to overcome weaknesses at work place

8) The Management of professional institutions should not take academicians for granted

9) The Management of professional institutions should not treat academicians badly

10) The Management should always ask what they actually want out of work performance at this level

11) The Management should always consider each academician's age and life stage while designing and assigning roles and responsibilities

12) The Management should always match motivator factors to the institution's or department's culture.

13) The Management should always use flexibility (Flexi assignment) wisely. They must allow academicians to telecommute some of the time as per convenience

14) The Management should always offer help with career goals and also design and develop carreer path as per overall performance

15) The Management should always provide congenial working environment, it is extremely important to maintain a positive attitude towards work

16) The Management should use the open door policy as per the rquirement of time and nature

17) The Management should always leave room for error in every line of work. It is important for the Management to assess the creativity and competency of its staff

18) The Management should always keep in mind that motivation must come from within each person. No leader is ever the single and should try to avoid some misconceptions like-

- 'everyone is like me'

- 'no-one is like me'

- 'people don't listen to me'

- 'some people can't be motivated'

- 'but I am listening'

- 'people will rise to tough challenges'

- 'this type of motivation takes too much time'

\section{B. Recommendations for Professional Academicians}

Academicians should try to increase psychological androgyny characteristics at work place

1) Male academicians should openly express feelings of love, fear, anger, pain, joy, loneliness and dependency. 
2) Male academicians should personalize experience rather than rely on objectivity and rationality

3) Male academicians should build support system to contribute overall productivity and to show androgyny personality characteristics

4) Male academicians should also learn how to fail at a task without feeling that one has failed as a man, it helps to build androgyny personality characteristics

5) Male academicians may also maintain androgyny features and should value an identity that is not so totally defined by work

6) Male academicians should show androgyny personality by listening empathetically and actively

7) Female academicians need to cultivate androgyny personality by being powerful and forthright and have a direct visible impact on others

8) Female academicians should show creativity and innovativeness while taking any risk at work place like entrepreneur to develop and prove psychological androgyny personality

9) Female academicians should state own needs and refuse to back down to prove at work place

10) Female academicians should recognize equal importance of accomplishing the task as well being concerned about relationship

11) Female academicians should be able to intellectualize and generalize

12) Female academicians should respond directly with 'I' statement rather than 'you' statements

\section{Recommendations for further research}

1) For further research one should try to keep accuracy in collection, analysis and interpretation of data

2) Further research may increase the scope of research study and the concept of androgyny may be elaborated with the hormonal composition of human being

3) Further, researcher may conduct the research study for employees from other industrial sectors as well

\section{REFERENCES}

[1] Aswathappa K "Human Resource Management" Fifth Edition Tata Mc Graw Hill

[2] New Delhi, 2005

[3] Bhargava, Harsh and Singh, Shailja. "Motivating B P O Academicians" Magazine Global CEO Volume VII January 2006, The ICFAI University Press, Hyderabad.

[4] Black Ken "Business Statistics" for contemporary decision making, fourth edition Willy India Edition 2008
[5] Chandan Jit S "Organizational Behavior" Third Edition, Vikas Publishing House New Delhi, pp 50-65, 2006

[6] Chandler Steve and Richardson Scott - "100 ways to motivate others" (How great leaders can produce insane results without driving people crazy) Jaico Publishing House Culcutta. 2006

[7] Charles W L Hill, Steven L Mc Shane "Principle of Management" Tata Mc Graw Hill New Delhi, 2008

[8] Chebolu Radha Mohan Employee Empowerment- "A workplace strategy for motivation" Magazine HRM Review volume VI February 2005, The ICFAI University press, Hyderabad.

[9] Cooper Donald R., Schindler Pamela S. "Business Research Methods" Current Edition Tata Mc Graw Hill New Delhi, 2010

[10] Desseler Gary "Human Resource Management" Eleventh edition Pearson Education 2009

[11] Diwedi R S "Human Relation and Organizational Behavior" A Global Perspective, Forth Edition Macmillan India Limited new Delhi pp 149 to 158.2006

[12] Ganesh M P "Work Motivation and Occupational Stress among Executives from Software and Manufacturing Industries" The I C F AI journal of Institutional Behavior Volume V, January 2006.

[13] Greenberg Jerald and Baron Robert A "Behavior in Organization" Ninth Edition Prentic Hall India Private Limited, 2007

[14] Hersey Paul, Blanchard Kenneth H., Johnson Dewey E Management of Organizational Behavior Utilizing Human resources, Ninth Edition Prentic Hall India Private Limited, 2008

[15] Kaptan Sanjay S, Murthy Latha SK - "Barriers to Motivation (How to Break Them)" Magazine Effective Executive Volume IX December 2006. The ICFAI University.

[16] Kulkarni Smita "Employee Motivation" Magazine Global CEO Volume VII November 2005, The ICFAI University press, Hyderabad.

[17] Luthans Fred "Organizational Behavior" Eleventh edition, Tata Mc Graw Hill New Delhi pp 160 to 215, 2008

[18] McKenna, E (2000) Business Psychology and Organizational Behavior, East Sussex: Psychology Press Ltd.

[19] Newstrom John W. and Davis Keith "Organizational Behavior" (Human Behavior at Work) Twelfth Edition Tata Mc Graw Hill New Delhi, 2006

[20] Pareek Udai "Effective Organizations beyond Management to Institution Building" Oxford and I B H Publishing House Private Limited pp 112 to 146.2002

[21] Pareek Udai "Understanding Organizational Behavior" Oxford University Press 2004

[22] Pattanayak Biswajeet "Human Resource Management" Prentice Hall India Private Limited pp 169-191, 2004

[23] Prashad L M "Institution Behavior" Eleventh Edition Sultan Chand and Son's New Delhi pp 144 to 191. 2007

[24] Robbins Stephen P, Judge Timothy A, Sanghi Seema "Organizational Behavior" Twelfth Edition Prentice Hall India Private Limited 2008

[25] Shajahan S. "Research Methods for Management" Fourth Edition, Jaico Publishing House Mumbay, 2006

[26] Shivalingam T. "Fundamental of Management" First Edition, Varinda Publication, pp 302-336, 2005

[27] Sudha G. S “Management Concept and Institutional Behavior" First Edition Ramesh Book Depot Jaipur pp 257 to 292, 2008

[28] Ttomas H. Spottsl, Mary Ann Bowman, and Christopher Mertz "Gender and use of Instructional technologies A study of University Faculty" Journal Higher Education, December 1997.

[29] Weihrich Heinz, Cannice V Mark, Koontz Harold "Management" a global entrepreneurial perspective, Twelfth Edition, Prentice Hall India Private Limited pp326-333, 2008 